Abstracta Iranica Abstracta Iranica

Revue bibliographique pour le domaine irano-aryen

Volume 22 | 2001

Comptes rendus des publications de 1999

Barnāme-rīzīe šahr-hā-ye jadìd / New Towns Planning. Tehrān, Samt, 1999/1378, 182 p., nbx tabl. et fig., biblio.

Marcel Bazin

(2) OpenEdition

Journals

Édition électronique

URL : http://journals.openedition.org/abstractairanica/37331

DOI : 10.4000/abstractairanica.37331

ISSN : 1961-960X

Éditeur :

CNRS (UMR 7528 Mondes iraniens et indiens), Éditions de l'IFRI

Édition imprimée

Date de publication : 15 mai 2001

ISSN : 0240-8910

Référence électronique

Marcel Bazin, « Barnāme-rīzīe šahr-hā-ye jadīd / New Towns Planning. Tehrān, Samt, 1999/1378, 182 p., nbx tabl. et fig., biblio. », Abstracta Iranica [En ligne], Volume 22 | 2001, document 636, mis en ligne le 17 février 2010, consulté le 09 octobre 2020. URL : http://journals.openedition.org/abstractairanica/ 37331 ; DOI : https://doi.org/10.4000/abstractairanica.37331

Ce document a été généré automatiquement le 9 octobre 2020.

Tous droits réservés 


\title{
Barnāme-rīzī-e šahr-hā-ye jadìd / New Towns Planning. Tehrān, Samt, 1999/1378, 182 p., nbx tabl. et fig., biblio.
}

\author{
Marcel Bazin
}

Cet ouvrage associe une présentation générale des villes nouvelles, de leur genèse, de leur classification et de leur répartition dans le monde (chapitres 1 à 3, pp. 1-77) et une étude des villes nouvelles iraniennes, dont le nombre doit dépasser la vingtaine : leur insertion dans le système urbain iranien (chapitre 4, pp.78-100), leur mode de planification (chapitre 5, pp. 101-147) et une typologie introduisant des études de cas, celles de Pardīs près de Téhéran et de Šāhīnšahr et Pūlādšahr autour d'Eșfahān (chapitre 6, pp. 148-176).

INDEX

Thèmes : 15.1. Iran

\section{AUTEURS}

MARCEL BAZIN

Université de Reims 